\title{
ヤマノイモの種芋消毒方法が青かび病の発生 および生育・収量に及ぼす影響
}

\author{
前川和正・高木 廣 \\ （兵庫県立農林水産技術総合センター）
}

2003年頃より兵庫県のヤマノイモ産地に扔いて, 貯蔵 中の種芋が青かび病により腐敗したり, 定植後の種芋が 腐敗して萌芽しないことがあり, 問題となった。そこで, 種芋消毒用の殺菌剤の種類，また消毒後定植までの種芋 の保存方法・期間等が, 青かび病の発生および生育・収 量に及ぼす影響を検討したので報告する。

\section{材料および方法 \\ 試験 1 種芋消毒方法が発病および生育・収量に及ぼす 影響}

試験は兵庫県朝来市，北部農業技術センターにおいて 実施した。2006年 4 月19日, 約 $50 \mathrm{~g}$ に切断したヤマノイ モ（品種：青波）種芋切片に $3 \times 10^{7}$ 個 $/ \mathrm{ml}$ の Penicillium $s p$. 分生胞子眯濁液をクロマト用噴霧器で噴霧し, ポリ 袋内で 2 時間静置した。その後，種芋消毒を行った。処 理は(1)イミノクタジンアルベシル酸塩30\%水和剂（フロ アブル）200倍液・10分浸漬。(2)チウラム・ベノミル水 和剂200倍液・10分浸漬 (3)消石灰粉衣（殺菌剂無処理） (4)無処理，とした。消毒後，芋切片をポリ袋（保湿条 件）に入れ, 室温（約 $17^{\circ} \mathrm{C}$ ) で定植まで 9 日間保存した。 区制は，1区，12切片・3 反復とした。 4 月 28 日，定植 直前に種芋切片断面での青かび病の菌そう発生面積を調 査した。発病調査後の切片を当センター内围場に定植し た。区制・面積は 1 区 $3.5 \mathrm{~m}^{2} ， 12$ 株・ 3 反復とした。定 植後， 6 月 19 日， 7 月 5 日に萌芽率を，11月 8 日の収穫 時，收穫芋表面と種芋切片表面での青かび病の菌そう発 生芋率，および収量を調査した。

試験 2 消毒後, 定植までの種芋保存方法・期間が発病 および生育・収量に及ぼす影響

試験 1 と同様に接種した種芋切片を用い第 2 表のよう に 8 種類の処理を行った。区制は，1区，12切片・3 反 復とした。定植直前に種芋切片の青かび病菌そう発生面 積を調查し，その後，試験 1 と同じ戋場に定植した。区
制・面積, 萌芽率, 収穫時の青かび病の発生および収量 調査は試験 1 と同様とした。

\section{結果および考察}

試験 1 : イミノクタジンアルベシル酸塩区では, 定植 時の種芋切片の青かび病菌そうは認められず，収穫時の 菌そうの発生も収穫芋, 種芋とも認められず, 高い防 除効果が認められた (第 1 表)。イミノクタジンアルベ シル酸塩区では， 6 月19日の萌芽率は $88.9 \%$ と高く, 初 期生育が良好で, 収量も $129.5 \mathrm{~kg} / \mathrm{a}$ と無処理の約 2 倍で あった（第 1 表）。

試験 2：6 月19日の萌芽率は, 種芋消毒・保湿した場 合，室温・5 日保存区で $97.2 \%$ と最も高く，室温・9 日 区，室温・13日区， $5^{\circ} \mathrm{C} \cdot 9$ 日区でも高く, 初期生育が 良好であった。しかし，消毒しても乾燥条件では $58.3 \%$ と低下し, 無消毒の 2 つの区では $0.0,5.6 \%$ と極端に低 下した（第 2 表）。無消毒の場合，乾燥条件で保存する と 7 月 5 日の茎長 $50 \mathrm{~cm}$ 以上の萌芽率が $25.0 \%$ と低く, 初期生育が遅延した (第 2 表)。種芋消毒後, 保湿条件 で保存した場合，温度・期間および消石灰粉衣の有無に かかわらず，収量は $127.9 〜 143.4 \mathrm{~kg} / \mathrm{a}$ と多い傾向であっ たが，乾燥条件では $117.7 \mathrm{~kg} / \mathrm{a}$ とやや低下した。無消毒 の場合，保湿区，乾燥区で，それぞれ 118.4，69.2 kg/a と乾燥条件で収量が極端に低下した（第 2 表）。

イミノクタジンアルベシル酸塩水和剤（フロアブル） による種芋消毒は青かび病菌に対して高い殺菌作用を示 し, その結果, 初期生育の促進をもたらし, 収量の増加 にも結びついたと考えられる。消石灰粉衣により菌そう 面積率が低下したが，これは切断面に石灰が付着するこ とで, 青かび病菌の分生胞子の増殖が物理的に抑制され たためと思われれる。

農家は種芋消毒を一度に行い，その後徐々に定植する が, 消毒後の保存方法の違いにより青かび病の発生に差

Kazumasa Maekawa and Hiroshi Takaki (Hyogo Pref. Tech. Cent. for Agric. Forest. and Fish.): Influence of seed potato disinfection methods of Chinese yam on occurrence of blue mold, growth and yield 2009年 2 月 12 日受理 
第 1 表＼cjkstart種芋消毒方法が青かび病の発生およびャマノイモの生育・収量に及ぼす影響（試験 1)

\begin{tabular}{|c|c|c|c|c|c|c|c|c|}
\hline \multirow{3}{*}{ 処理方法 } & \multirow{2}{*}{\multicolumn{2}{|c|}{$\begin{array}{c}\text { 定植時, 種芋切片切断面で_ } \\
\text { の青が病（菌そう） }\end{array}$}} & \multicolumn{3}{|c|}{ 萌芽率（\%） } & \multirow{2}{*}{\multicolumn{2}{|c|}{$\begin{array}{l}\text { 収穫時の青かび病 } \\
\text { (菌气発病芋率 }(\%)\end{array}$}} & \multirow{3}{*}{ 収量（kg/a） } \\
\hline & & & \multirow[b]{2}{*}{6 月19日 } & \multicolumn{2}{|c|}{7 月 5 日 } & & & \\
\hline & $\begin{array}{c}\text { 発病切片率 } \\
(\%)\end{array}$ & $\begin{array}{c}\text { 菌そう面積率 } \\
(\%)\end{array}$ & & $\begin{array}{l}\text { 茎長 } 50 \mathrm{~cm} \\
\text { 未満 }\end{array}$ & $50 \mathrm{~cm}$ 以上 & 収穫芋 & 種芋 & \\
\hline イミノクタジン1) & 0.0 & 0.0 & 88.9 & 0.0 & 97.2 & 0.0 & 0.0 & $129.5 \pm 7.9$ \\
\hline チウラム・ベノミル22) & 100.0 & 50.0 & 0.0 & 22.2 & 27.8 & 21.1 & 60.0 & $61.0 \pm 6.9$ \\
\hline 消石灰粉衣 ～～～～ & 97.2 & 7.3 & 0.0 & 44.4 & 38.9 & 5.6 & 52.6 & $79.7 \pm 9.8$ \\
\hline 無処理 & 100.0 & 85.0 & 0.0 & 30.6 & 16.7 & 41.3 & 68.4 & $65.4 \pm 12.9$ \\
\hline
\end{tabular}

1）イミノクタジンアルベシル酸塩水和剂（フロアブル）200倍に10分浸漬。2）チウラム・ベノミル水和剂200倍に10分浸漬。2006年 4 月19日種芋消毒し, 保湿・室温条件で定植まで 9 日間保存した。定植 4 月 28 日, 収穫11月 8 日。表中の数字は 3 反復の平均值を示す。 収量は平均値士標準䛊差を示す。

第 2 表＼cjkstart種芋消毒後の種芋保存方法が青かび病の発生およびヤマノイモの生育・収量に及ぼす影響（試験 2）

\begin{tabular}{|c|c|c|c|c|c|c|c|c|c|c|}
\hline \multirow{3}{*}{ 種芋消毒 } & \multirow{3}{*}{$\begin{array}{l}\text { 消毒後 } \\
\text { 保存湿度 } \\
\text { 条件 }\end{array}$} & \multirow{3}{*}{$\begin{array}{l}\text { 消毒後 } \\
\text { 保存温度 }\end{array}$} & \multirow{3}{*}{$\begin{array}{c}\text { 消毒後 } \\
\text { 保存期間 } \\
(\text { (日) }\end{array}$} & \multirow{3}{*}{$\begin{array}{c}\text { 種芋切片 } \\
\text { での青か } \\
\text { び病登病 } \\
\text { 切片率1 } \\
(\%)\end{array}$} & \multicolumn{3}{|c|}{ 萌芽率（\%) } & \multirow{2}{*}{\multicolumn{2}{|c|}{$\begin{array}{c}\text { 収穫時の青かび病 } \\
\text { (菌乞う) 発病芋率 (\%) }\end{array}$}} & \multirow{3}{*}{$\begin{array}{l}\text { 収量 } \\
(\mathrm{kg} / \mathrm{a})\end{array}$} \\
\hline & & & & & \multirow[b]{2}{*}{6 月19日 } & \multicolumn{2}{|c|}{7 月 5 日 } & & & \\
\hline & & & & & & $\begin{array}{l}\text { 茎長 } 50 \mathrm{~cm} \\
\text { 未満 }\end{array}$ & $\begin{array}{l}50 \mathrm{~cm} \\
\text { 以上 }\end{array}$ & 収穫芋 & 種芋 & \\
\hline $\mathrm{I}^{2)}$ & 保湿 & 室温 & 5 & 0.0 & 97.2 & 0.0 & 100.0 & 0.0 & 0.0 & $127.9 \pm 12.3$ \\
\hline $\mathrm{I}^{2)}$ & 保湿 & 室温 & 9 & 0.0 & 88.9 & 0.0 & 97.2 & 0.0 & 0.0 & $129.5 \pm 7.9$ \\
\hline $\mathrm{I}^{2)}$ & 保湿 & 室温 & 13 & 0.0 & 83.3 & 2.8 & 94.4 & 2.8 & 0.0 & $143.4 \pm 6.6$ \\
\hline $\mathrm{I}^{2)}$ & 保湿 & $5^{\circ} \mathrm{C}$ & 9 & 0.0 & 86.1 & 2.8 & 97.2 & 0.0 & 0.0 & $135.1 \pm 15.4$ \\
\hline $\mathrm{I}^{2)}+\mathrm{L}^{3)}$ & 保湿 & 室温 & 9 & 0.0 & 83.3 & 0.0 & 83.3 & 2.6 & 0.0 & $141.5 \pm 9.7$ \\
\hline $\mathrm{I}^{2)}$ & 乾燥 & 室温 & 5 & 0.0 & 58.3 & 11.1 & 88.9 & 0.0 & 0.0 & $117.7 \pm 15.1$ \\
\hline 無 & 保湿 & 室温 & 5 & $-^{4)}$ & 5.6 & 19.4 & 63.9 & 7.2 & 23.5 & $118.4 \pm 27.6$ \\
\hline 無 & 乾燥 & 室温 & 5 & - $^{4)}$ & 0.0 & 55.6 & 25.0 & 11.6 & 10.0 & $69.2 \pm 7.9$ \\
\hline
\end{tabular}

1）定植時, 種芋切断面での青かび病菌そうの発生。2）イミノクタジンアルベシル酸塩水和剂（フロアブル）200倍に10分浸漬浸漬。3） 消毒後, 消石灰粉衣。4）未調査。種芋消毒 : 2006年 4 月 19 日, 定植 4 月 24 日, 28 日， 5 月 2 日, 収穫 11 月 8 日。表中の数字は 3 反復 の平均値を示す。収量は平均値士標準誤差を示す。

があることが推察されたので, 保存方法の試験を実施し た。保存期間について，無消毒・保湿条件では短い方が 增収した。消毒後保湿保存した場合，5，9，13日の間で 初期生育，収量に大差はなく，13日間保存することが可 能であった。また，消毒後保湿した場合，室温 $\left(17^{\circ} \mathrm{C}\right)$, $5^{\circ} \mathrm{C}$ の温度間で，初期生育，収量に大差はなく， あえて 冷蔵する必要はなかった。

保存中に芋切片を乾燥させると，初期生育が遅れ，収 量が低下する傾向にあり，特に無消毒では，顕著な減収 が認められた。芋類が負傷した場合，傷口の柔組織に癒 傷木栓層が形成され，これが病原菌の侵入を阻止するが, その形成には芋の活力と湿度が影響する4)。ヤマノイモ の種芋は保湿状態で冬期貯蔵すると活力が高く，貯蔵中 での青かび病の発生も少ない3)。また，ナガイモにおい て， $28^{\circ} \mathrm{C}$ ・相対湿度 $100 \%$ で3日または 5 日のキュアリン グ処理 ${ }^{2)}$ や， $20^{\circ} \mathrm{C} ・$ 相対湿度 $95 \%$ 以上・ 7 日間のキュア リング处理 ${ }^{1)}$ により青かび病の発病が減少したと報告さ
れている。これらのことから種芋切片を保湿して保存す ることが，青かび病に対する抵抗性を強化すると考えら れる。

以上の結果から, 青かび病に対する種芋消毒として, 種芋切片をイミノクタジンアルベシル酸塩水和剤（フロ アブル）に漬浸後，種芋を保湿条件に保ち，少なくとも 消毒後13日以内に定植することが望ましい。

\section{引用文献}

1）北海道十勝農業試験場（2005）平成16年度北海道農業試験 会議資料, pp. 1-27.

2）岩田 勉・土屋貞夫・児玉不二雄（1979）日植病報 45 ： $115-116$.

3）前川和正（2008）関西病虫研報 $50: 115-116$.

4) 山本和太郎 - 吉谷啓作 - 前田已之助（1955）兵庫農科大研 報 2-1: 69-79. 